\title{
ASSESSMENT OF STUDENTS' HEALTH CONDITION BY INDICATORS OF ADAPTATION POTENTIAL, BIOLOGICAL AGE AND BIO-ENERGETIC RESERVES OF ORGANISM
}

Martyniuk O.V., Vilyanskiy V.N.

National mining university

\begin{abstract}
Purpose: to assess students' health condition by indicators of adaptation potential, biological age and expressassessment. Material: in the research 47 first and second year girl students participated, who belonged to main health group. Results: we distributed the girl students into three groups: $14.89 \%$ of them were included in group with "safe" health condition; 34.04\% - in group of "third state"; $51.06 \%$ were related to group with "dangerous" health condition. We established that dangerous level was characterized by energy potential of below middle and low level. It is accompanied by accelerated processes of organism's age destructions and tension of regulation mechanisms. Conclusions: the received results permit to further develop and generalize the data of students' health's assessment by indicators of adaptation potentials, biological age and physical health's condition.
\end{abstract}

Key words: assessment, level, health, students, youth.

\section{Introduction}

It is known that in order to preserve and strengthen health of sound people information about conditions of health's formation, final result of this information's realization: specific indicators, characterizing individual's or population's health condition, is required [1, C. 22]. Besides, some authors [6, 8, 25-28, 32, 33] noted that for effective realization of health related tasks in process of students' physical education it is necessary to implement objective criteria of assessment of students' health in educational process. The choice of assessment's diagnostic model depends on the purpose of research. With it, the main thing will be not rather symptomatic, but interpretation and combining in certain wholeness of diagnostic results when finally forming summarizing conclusions about organism's status [22].

In the course of our researches we found that by the present time, for assessment of students' health condition and for study of effectiveness of health related physical culture methodic the most popular and actual have been the following models:

- pre-nosological diagnostic [7, 20, 23, 24] - assessment of organism's functional state as well as its adaptation potentials in period, when obvious symptoms of disease are absent;

- diagnosing by direct indicators - determination of biological age $[4,16,17,19]$ and assessment of organism's energy potential (bio-energy reserves) [5, 6, 8, 11], which characterize biological function of survival (as one of main signs of health) [2].

We have found significant quantity of works, devoted to these problems [29-31, 34-39]. Alongside with it, there are single publications [10, 14] about results of application of complex approach to assessment of human health's condition by indicators of adaptation potential, biological age and by bio-energetic reserves.

The above mentioned conditions urgency of our work and the received results permit to expand and supplement existing data about assessment of students' health.

Purpose, tasks of the work, material and methods

The purpose of the work is: on the base of complex approach to assess students' health condition by indicators of adaptation potential, biological age and express-assessment.

Material and methods: As a result of generalization of theoretical knowledge and practical experience of specialists $[4,6,10,15,17,18,20,21,40-47]$ we selected simple and accessible methods of health's assessment. Their usage does not create any organizational and material-technical difficulties in process of mass testing: methodic of adaptation potential's determination by R.M. Bayevskiy; methodic of biological age determination [14] and determination of bioenergy reserves by express-assessment of physical health [9].

Pedagogic experiment was conducted at the beginning of 2014-2015 academic year on base of physical education and sports' department of State HEE "National mining university" (Dniepropetrovsk). In the research 47 first and second year girl students participated, who belonged to main health group.

() Martyniuk O.V., Vilyanskiy V.N., 2015

http://dx.doi.org/10.15561/20755279.2015.0303 


\section{Results of the research}

In table 1 we present students' quantitative distribution into groups by adaptation potentials', biological age indicators and by results of express assessment.

Table 1

Quantitative distribution into groups by adaptation potentials', biological age indicators and by results of express assessment, received in the course of pedagogic experiment (\%), ( $n=47)$

\begin{tabular}{|c|c|c|c|c|c|c|c|c|c|c|c|c|c|}
\hline \multirow{2}{*}{\multicolumn{2}{|c|}{ Health levels }} & \multicolumn{2}{|c|}{ By AP } & \multicolumn{5}{|c|}{ By biological age } & \multicolumn{5}{|c|}{ By express assessment } \\
\hline & & 1 & 2 & 1 & 2 & 3 & 4 & 5 & $\mathrm{HL}$ & AML & ML & BML & LL \\
\hline \multirow{2}{*}{ By AP } & 1 & & & 4.26 & 6.38 & $\begin{array}{c}12.7 \\
7\end{array}$ & 8.51 & 2.13 & 4.26 & 10.64 & 17.02 & 2.13 & - \\
\hline & 2 & & & 2,13 & $\begin{array}{c}10.6 \\
4\end{array}$ & 6.38 & $\begin{array}{c}25.5 \\
3\end{array}$ & $\begin{array}{c}21.2 \\
7\end{array}$ & - & - & 17,02 & 29.78 & 19.14 \\
\hline \multirow{5}{*}{ 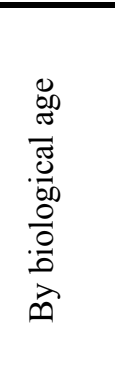 } & 1 & 4.26 & 2.13 & & & & & & 2.13 & 2.13 & - & 2.13 & - \\
\hline & 2 & 6.38 & 10.64 & & & & & & 2.13 & 2.13 & 6.38 & 4.26 & 2.13 \\
\hline & 3 & 12.77 & 6.38 & & & & & & - & 4.26 & 10.64 & 2.13 & 2.13 \\
\hline & 4 & 8.51 & 25.53 & & & & & & - & 2.13 & 10.64 & 14.89 & 6.38 \\
\hline & 5 & 2.13 & 21.27 & & & & & & - & - & 6.38 & 8.51 & 8.51 \\
\hline \multirow{5}{*}{ 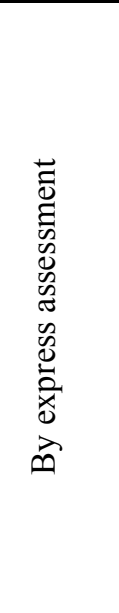 } & BУ & 4.26 & - & 2.13 & 2.13 & - & - & - & & & & & \\
\hline & $\begin{array}{c}\mathrm{BC} \\
\mathrm{y}\end{array}$ & 10.64 & - & 2.13 & 2.13 & 4.26 & 2.13 & - & & & & & \\
\hline & $\mathrm{CY}$ & 17.02 & 17.02 & - & 6.38 & 10.6 & 10.6 & 6.38 & & & & & \\
\hline & $\begin{array}{c}\mathrm{HC} \\
\mathrm{y}\end{array}$ & 2.13 & 29.78 & 2.13 & 4.26 & 2.13 & $\begin{array}{c}14.8 \\
9\end{array}$ & 8.51 & & & & & \\
\hline & НУ & - & 19.14 & - & 2.13 & 2.13 & 6.38 & 8.51 & & & & & \\
\hline
\end{tabular}

With distribution of experiment's participants by adaptation potentials' indicators (AP) we accepted as the basis standard values for students [21], which were worked out on the base of centile corridors' method:

- satisfactory adaptation, $1^{\text {st }}$ group, not more than 2 conv.un.;

- tension of adaptation mechanisms, $2^{\text {nd }}$ group, 2.11 conv.un.;

- unsatisfactory adaptation, $3^{\text {rd }}$ group, $3.21-4.30$ conv.un.;

- failure of adaptation, $4^{\text {th }}$ group, from 4.30 and more.

By results of AP registration we received:

- First group - satisfactory adaptation was registered in $34.04 \%(n=16)$ students; 
- Second group - tension of adaptation mechanisms - in $65.96 \%(n=31)$. It should be noted that there were not found any students with unsatisfactory adaptation or with failure of adaptation.

By results of determination of biological age (BA) we found:

- First level of health - slow ageing of organism was registered in $6.38 \%(\mathrm{n}=3)$ students;

- Second level of health - middle temps of organism's ageing - in $17.02 \%(n=8)$;

- $\quad$ Third level of health - coincidence of biological and calendar age was registered in $19.15 \%(\mathrm{n}=9)$;

- Forth level of health - accelerated organism's ageing - in 34.04\% ( $\mathrm{n}=16)$;

- $\quad$ Fifth level of health - quick temps of organism's ageing - in $23.40 \%(\mathrm{n}=11)$.

By results of express-assessment we received:

- High level of physical health (HL) was registered in $4.26 \%(\mathrm{n}=2)$,

- $\quad$ Above middle level of physical health (AML) - in 10.64\% ( $\mathrm{n}=5)$,

- $\quad$ Middle level of physical health (ML) - in 34.04\% ( $\mathrm{n}=16)$,

- Below middle level of physical health (BML) - in 31.91\% $(\mathrm{n}=15)$,

- Low level of physical health (LL) - in 19.14\% $(\mathrm{n}=9)$.

The data of table 2 witness that weakening of organism's bio-energetic reserves is accompanied by organism's accelerated ageing and tension of adaptation mechanisms. And vice versa, weakening of regulatory mechanisms' functioning is followed by reduction of bio-energy reserves and acceleration of organism's ageing. For determination of confidence and degree of statistic correlation between adaptation potentials' indicators, biological age and results of express assessment we conducted correlation analysis (see fig. 1).

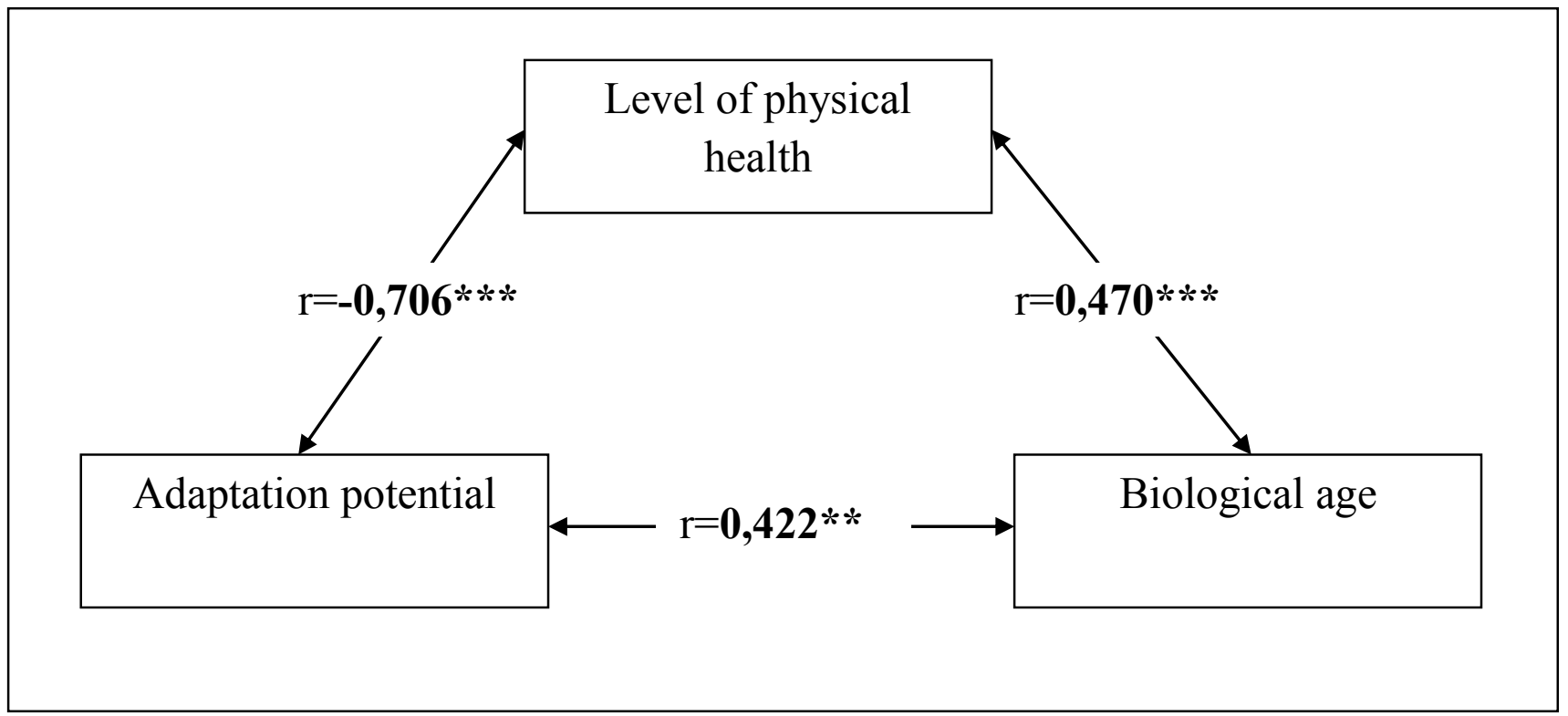

$* * * \alpha \leq 0.001, * * \alpha \leq 0.01$

Fig.1. Correlation between adaptation potentials' indicators, biological age and level of physical health, $(n=47)$

We detected that for the given category the most informative indicator by high absolute value of correlation coefficient was level of physical health (LPH). For example, LPH has significant confident correlation with adaptation potential ( $\mathrm{r}=-0.706, \alpha \leq 0.001)$ and moderate with biological age $(\mathrm{r}=0.470, \alpha \leq 0.001)$.

Following "energetic" conception by G.L. Apanasenko [1], at finalizing stage of the researches, by the obtained results students were distributed into three groups (see table 2). 
Table 2

Comparative analysis of mean-statistic values of indicators of morphological-functional indices of express assessment, adaptation potential, biological age of students depending on health level, which were received in the course of experiment, $(n=47)$

\begin{tabular}{|l|c|c|c|}
\hline \multirow{2}{*}{ Indicators } & \multicolumn{2}{|c|}{$\bar{x} \pm \sigma$} & "dangerous" level of health \\
\cline { 2 - 4 } & "safe" level of health & "third state" & \\
\hline MHI, g/cm & $305.73 \pm 23.59$ & $339.27 \pm 31.51$ & $43.17 \pm 8.89$ \\
\hline SI, conv.un. & $57.67 \pm 7.76$ & $46.41 \pm 6.54$ & $99.51 \pm 12.42$ \\
\hline DP, conv.un. & $69.61 \pm 18.72$ & $91.93 \pm 16.05$ & $2.25 \pm 0.47$ \\
\hline PWC 170, BT/KГ & $2.81 \pm 0.14$ & $2.48 \pm 0.28$ & $14.88 \pm 5.15$ \\
\hline IRuffiet, conv.un. & $8.17 \pm 3.29$ & $10.35 \pm 3.30$ & $5.88 \pm 2.69$ \\
\hline LPH, points & $16.57 \pm 2.44$ & $11.5 \pm 1.59$ & $2.36 \pm 0.04$ \\
\hline AP, conv.un. & $1.74 \pm 0.26$ & $2.17 \pm 0.32$ & $32.37 \pm 8.21$ \\
\hline BA, years & $23.43 \pm 7.07$ & $30.22 \pm 5.90$ & $27.56 \pm 0.50$ \\
\hline PBA, years & $27.59 \pm 0.55$ & $27.50 \pm 0.47$ & \\
\hline BA-PBA, years & $-4.16 \pm 7.09$ & $2.71 \pm 5.83$ & \\
\hline
\end{tabular}

Notes: MHI - mass-height index, SI - strength index, DP - “double product”, IRuffiet - Ruffiet's index, PBA proper biological age, BA - PBA difference between biological age and proper biological age.

In group with "safe" health level insignificant quantity of students were included- $14.89 \%$ (n=7) with high and above middle LPH. 34.4\% ( $\mathrm{n}=16)$ of students were related to group of "third state" (students with middle LPH. In group with "dangerous" health level rather significant quantity of students were included-51.06\% ( $\mathrm{n}=24)$ with LPH low and below middle.

Comparative analysis of mean statistic values of indicators resulted in the following: it was established that "safe" level of health is characterized by the lowest values of mass-height index, index "double product" and Ruffiet's index as well as adaptation potential, biological age with, at the same time, with high strength index's indicators as well as $\mathrm{PWC}_{170}$ index.

It is known that biological age and organism's energy potential (bio energy reserves) characterize biological function of survival as one of main manifestations of health. [2]. Considering this aspect, we distributed students with middle LPH in group, named "third state". According to mean statistic indicators this group is characterized by middle level of organism's reserves, by coincidence of biological age with calendar one. However in this group we noticed tension of adaptation.

Thus, we can assume that this category of students is on the border of transition from healthy conditions to predisease state [3].

Accordingly, "dangerous" level of health is characterized as below middle and low level of energy potential and is accompanied by accelerated age-destruction processes and tension of all regulation mechanisms. 


\section{Discussion}

Recent time assessment of students' health condition by indicators of their regulatory mechanisms, "age wearing out"; by morphological - functional structures in organism per unit of biological time and by indicators of bio-energy reserves has been becoming the subject of multiple researches, in which students participate.

In general, the received by us data supplemented, expanded and in some cases coincided with results of most of researches in this direction. However, still there are some distinctions. For example our data a little differ with information of other authors [7, 24] in our using of standard values of adaptation potential for students. It concerns the students, who have satisfactory adaptation and tension of its mechanisms. With it we confirmed the existing conclusions about absence of unsatisfactory adaptation or its failure among students.

There are also some distinctions in distributions of experiment's participants by indicators of biological age in comparison with other authors (see table 4).

Table 4

Quantitative distribution of students by indicators of biological age, fulfilled by different authors, (\%)

\begin{tabular}{|c|c|c|c|c|c|c|c|}
\hline \multirow{2}{*}{ Authors } & \multirow{2}{*}{\multicolumn{2}{|c|}{ Contingent }} & \multicolumn{5}{|c|}{ Health levels by BA } \\
\hline & & & 1 & 2 & 3 & 4 & 5 \\
\hline Own data, (2015) & gi & & 6.38 & 14.89 & 19.15 & 36.17 & 23.40 \\
\hline \multirow{2}{*}{ Ye.V. Tserkivnaya et al., (2011) } & \multirow{2}{*}{ girls } & EG & - & 9 & 15 & 45 & 31 \\
\hline & & $\mathrm{CG}$ & - & - & 10.6 & 38.5 & 50.9 \\
\hline I.E. Kopko et al., (2011) & \multicolumn{2}{|c|}{ girls } & - & - & 32 & 34 & 32 \\
\hline S.A. Korol, (2014) & \multicolumn{2}{|c|}{ girls } & - & - & 18.2 & 22.7 & 59.1 \\
\hline
\end{tabular}

Notes: EG - experimental group; $\mathrm{CG}$ - control group.

Nevertheless our data agree quite good with researches' results of the mentioned above authors in the aspect that high percentage of students have forth and fifth levels of health by BA, and, accordingly, accelerated and rapid temps of organism's ageing.

Comparative analysis of our results of express-assessment of students' health condition with results of other researchers we considered to not be correct, because different assessment methods were used.

However, we can compare with own results of earlier conducted experiment, in which women of mature age (2135 years) participated [14]. And the data received by us also a little differ. Among women of mature age $23.46 \%$ were registered as having high and above middle level of health, while among $1^{\text {st }} 2^{\text {nd }}$ year girl students - only $14.90 \%$.

It points at the fact that insignificant percentage of women of different age (in the given case of junior and age of first maturity) differ from their peers by "optimal" reserve of organism's bio energy. Also we can affirm that there is negative tendency to decreasing of health level among students of our country.

Thus, certain distinctive features of our work are that we did not render mean statistic characteristics of the received results. We conducted quantitative distribution of girls into groups by indicators of adaptation potential, biological age and express assessment of physical health (see table1).

Like some other researchers $[6,11,23]$ (who followed energetic conception by G.L. Apanasenko) we fulfilled distribution of students by results of express assessment into groups according to health level. With it the distinctive feature of our work is application of complex approach in our researches. Its results supplement the existing data about health condition of students.

The first group with high and above middle health levels was defined as "safe" level of health. It agrees with data of researches of L. Dolzhenko (2004) and S.A. Korol (2014). We supplemented that "optimal” reserve of organism's bioenergy is accompanied by satisfactory functioning of regulatory mechanisms and slow temps of organism's ageing. 
In available literature we could not find researches on distribution of students in group, defined as "third state": border of transition from healthy condition to pre-disease state. Our data (see table 2) witness about it. In opinion of G.L. Apanasenko [1], on the base of express assessment at pre-medical stage of examination of persons with middle health level, they can be considered as group "healthy".

The received characteristics of "dangerous" health level confirm scientific facts: the higher level of physical health is, the more balanced is adaptation [17], and the lower indicators of biological age are [12] and vice versa.

\section{Conclusions:}

The received in the course of pedagogic experiment results create opportunities for further development and generalization of students health condition's assessment by indicators of adaptation potential, biological age and physical health's level.

The prospects of further researches imply fulfillment of comparative analysis of indicators of adaptation potential, biological age, physical health of boys and girls $-1^{\text {st }}-2^{\text {nd }}$ year students of State HEE "National mining university".

\section{Acknowledgement}

The work has been fulfilled in compliance with combined plan of scientific - research governmentally financed work of physical education and sports' department of State HEE "National mining university" for 2013-2015 by topic "Usage of health related technologies at physical education classes in HEE and their influence on students' health condition".

\section{Conflict of interests}

The authors declare that there is no conflict of interests.

\section{References:}

1. Apanasenko GL. Evoliuciia bioenergetiki $i$ zdorov'e cheloveka [Evolution of bio-energetic and human health], Sankt Petersburg: Petropolis; 1992. (in Russian)

2. Apanasenko GL. Izbrannye stat'i o zdorov'e [Featured articles about health], Kiev; 2005. (in Russian)

3. Apanasenko GL. Diagnostika individual'nogo zdorov'ia [Diagnostic of individual health]. Available at: http://www.medlinks.ru/article.php?sid=43703. (accessed 02.06.2015). (in Russian)

4. Cerkovnaia EV, Nefedova AL, Osipov VN, Mirgorod OA. Biologicheskij vozrast i tempy stareniia studentov s raznym urovnem dvigatel'noj aktivnosti [Biological age and ageing temps of students with different level of motor functioning]. Physical education of students 2011;1:130-132. (in Russian)

5. Bushuiev IuV. Riven' fizichnogo zdorov'ia studentiv iak kliniko-fiziologichna osnova fizichnogo vikhovannia u vuzi. Cand. Diss.[Level of students' physical health as clinical-physioplogical basis of physical education in HEE. Cand. Diss.], Dnipropetrovsk; 2007. (in Ukrainian)

6. Dolzhenko L. Zakhvoriuvanist' i rukhova aktivnist' studentiv z riznimi rivniami somatichnogo zdorov'ia [Morbidity and motor functioning of students with different somatic health's levels]. Teoriia i metodika fizichnogo vikhovannia $i$ sportu 2004;1:21-23. (in Ukrainian)

7. Zakharina EA. Analiz fizicheskogo zdorov'ia studentov Klassicheskogo privatnogo universiteta [Analysis of physical health of students of Classic private university]. Pedagogics, psychology, medical-biological problems of physical training and sports 2009;7:61-64. (in Russian)

8. Zeleniuk O.V. Fizicheskoe vospitanie v upravlenii sostoianiem zdorov'ia studencheskoj molodezhi [Physical education in control over students' health]. Fiziceskoe vospitanie studentov tvorceskih special'nostej 2002;2:75-82. (in Russian)

9. Klapchuk VV., Samoshkin VV. Kil'kisna ocinka rivnia fizichnogo zdorov'ia ta rekreacijno-ozdorovchi rezhimi [Quantitative assessment of physical health and health related recreational regiments], Dnipropetrovsk: DDIFKIS; 2009. (in Ukrainian)

10. Kopko IIe, Fil' VM. Biologichnij vik iak biomarker diagnostiki rivnia zdorov'ia students'koi molodi [ Biological age as bio-marker of students' health diagnostic]. Naukovo-pedagogichni problemi fizichnoi kul'turi 2011;13:249254. (in Ukrainian)

11. Korol SA. Assessment of physical health and physical fitness of students of technical specialties of I course. Pedagogics, psychology, medical-biological problems of physical training and sports 2014;11:23-29. http://dx.doi.org/10.15561/18189172.2014.1105 
12. Krucevich TIu. Teoriia i metodika fizicheskogo vospitaniia [Theory and methodic of physical education], Kiev; 2003. (in Russian)

13. Loshic'ka TI. Biologichnij vik ta tempi starinnia organizmu studentiv [Biological age and temps of students organism's ageing]. Pedagogics, psychology, medical-biological problems of physical training and sports 2010;7:50-52. (in Ukrainian)

14. Martyniuk OV. Effektivnost' primeneniia krugovoj trenirovki na zaniatiiakh aerobikoj s zhenshchinami pervogo zrelogo vozrasta. Cand. Diss. [Effectiveness of circular aerobics n training of first maturity women. Cand. Diss.], Dnepropetrovsk; 2012. (in Russian)

15. Martiniuk Ol'ga, Pechena Valentina, Kravchenko Katerina. Analiz riznomanitnikh metodik ocinki rivnia fizichnogo zdorov'ia students'koi molodi [Analysis of different assessment methodic for students' physical health]. Fizichna kul'tura, sport ta zdorov'ia nacii 2014;1:183 - 189. (in Ukrainian)

16. Prisiazhniuk SI. Ocinka pokaznikiv biologichnogo viku i patologichnogo indeksu studentiv NUBIP Ukraini [Assessment of biological age indicators and pathological index of NUBIP students, Ukraine]. Naukovopedagogichni problemi fizichnoi kul'turi 2011;13:491-494. (in Ukrainian)

17. Prikhod'ko VV, Kuz'minskij VP. Kreativnaia valeologiia [Creative valueology], Dnepropetrovsk; 2004. (in Russian)

18. Raevskij RT, Kanishevskij SM. Zdorov'e, zdorovyj obraz zhizni i ozdorovitel'nyj obraz zhizni studentov [Health, healthy life style and students' health related way of life], Nauka i tekhnika; 2008. (in Russian)

19. Romanchishin O, Sidorko O, Dika M. Somatichne zdorov'ia, adaptacijnij potencial, fizichnij stan ta biologichnij vik studentiv pedagogichnogo koledzhu [Somatic health, adaptation potential, physical condition and biological age of pedagogic college students]. Pedagogics, psychology, medical-biological problems of physical training and sports 2010;11:98-101. (in Ukrainian)

20. Sivakov NN. Ispol'zovanie metodov donozologicheskoj diagnostiki v ocenke urovnia zdorov'ia cheloveka [Application of pre-nosological diagnostic methods in assessment of human health]. Teoriia i praktika fizicheskoj kul'tury 2002;9:8-11. (in Russian)

21. Solov'ev VN. Fizicheskoe zdorov'e kak integral'nyj pokazatel' urovnia adaptacii organizma studentov k uchebnomu processu [Physical health as integral indiator of students organism's adaptation to learning process]. Fundamental'nye issledovaniia 2005;6:61-66. (in Russian)

22. Prisiazhniuk SI, Krasnov VP, Tret'iakov MO, Raievs'kij RT, Kijko VJ, Panchenko VF. Fizichne vikhovannia [Physical education], Kiev: Center of educational literature; 2007.

23. Cap I. Riven' adaptacijnogo potencialu 19-21-richnikh studentok iz sekcii volejbolu [Level of adaptation potential of 19-21 years old girl students from volleyball circle]. Fizichne vikhovannia, sport $i$ kul'tura zdorov'ia $u$ suchasnomu suspil'stvi 2012;2:195-199. (in Ukrainian)

24. Iukhimenko SM. Analiz adaptacijnogo potencialu students'koi molodi [Analysis of students' adaptation potential]. Pedagogics, psychology, medical-biological problems of physical training and sports 2007;4:145-147. (in Ukrainian)

25. Abar B, Ogedegbe C, Dalawari P, Freeman K, Boudreaux ED, Illuzzi F. Promoting tobacco cessation utilizing prehealth professional students as research associates in the emergency department. Addictive Behaviors. 2015;40(0):73-6.

26. Al-Hariri MT, Al-Hattami AA. Utilization of internet by health colleges students at the University of Dammam. Journal of Taibah University Medical Sciences 2015;10(1):66-73.

27. Berger H, Franke GH, Hofmann F-H, Sperth M, Holm-Hadulla RM. Mental health of students and its development between 1994 and 2012. Mental Health \& Prevention 2015;3(1-2):48-56.

28. Dolan E, Hancock E, Wareing A. An evaluation of online learning to teach practical competencies in undergraduate health science students. The Internet and Higher Education 2015;24(0):21-5.

29. Feuerman VV. Influence of socio-philosophical and spiritual values on the formation of social orientation and physical health specialists the sphere of physical culture and sports. Physical Education of Students 2014;2:41-45. http://dx.doi.org/10.6084/m9.figshare.906859 
30. Goginava SE, Rumba OG. On improving effect combining aerobic and anaerobic loads of character in the classroom for physical training in universities. Physical Education of Students 2014;3:18-29. http://dx.doi.org/10.6084/m9.figshare.974492

31. Golod NR. Principles of developing a well-rounded program of physical rehabilitation for female students in the special medical group with consideration of physical activity impairment. Pedagogics, psychology, medicalbiological problems of physical training and sport 2015;5:9-15. http://dx.doi.org/10.15561/18189172.2015.0502

32. Hadden KB. Health literacy training for health professions students. Patient Education and Counseling 2015;98(7):918-20.

33. Holm-Hadulla RM, Koutsoukou-Argyraki A. Mental health of students in a globalized world: Prevalence of complaints and disorders, methods and effectivity of counseling, structure of mental health services for students. Mental Health \& Prevention 2015;3(1-2):1-4.

34. Iermakova TS. Development of the idea of forming health culture of a person in the world educational thought. Pedagogics, psychology, medical-biological problems of physical training and sports 2014;4:8-12. http://dx.doi.org/10.6084/m9.figshare.950949

35. Iermakova TS. Education of children in Polish family in a context of forming health culture. Pedagogics, psychology, medical-biological problems of physical training and sports 2014;11:17-22. http://dx.doi.org/10.15561/18189172.2014.1104

36. Iermakova TS. Forming a health culture of future teachers in Polish educational establishments. Physical Education of Students 2014;5:14-19. http://dx.doi.org/10.15561/20755279.2014.0503

37. Iermakova TS. Peculiarities of forming health culture of pupils in Poland: historical aspect. Pedagogics, psychology, medical-biological problems of physical training and sports 2014;6:16-20. http://dx.doi.org/10.6084/m9.figshare.1004090

38. Kozina ZhL, Kozhuhar LV, Sobko IN, Vaksler MA, Tihonova AA. Workability's recreation methodic with application of cupping massage and autogenic training of women student teams' basketball players. Pedagogics, psychology, medical-biological problems of physical training and sport 2015;5:16-21. http://dx.doi.org/10.15561/18189172.2015.0503

39. Lapkin S, Levett-Jones T, Gilligan C. Using the Theory of Planned Behaviour to examine health professional students' behavioural intentions in relation to medication safety and collaborative practice. Nurse Education Today 2015;35(8):935-40.

40. Malenyuk TV, Kosivska AV. Training at sport circle as priority form of organization of students' physical education (on example of shaping). Pedagogics, psychology, medical-biological problems of physical training and sports 2015;4:38-42. http://dx.doi.org/10.15561/18189172.2015.0407

41. Petrenko NV, Loza TA. Model of recreational and training sessions based on the use of funds aqua professionally applied in the preparation of students of economics. Physical Education of Students 2014;4:32-36. http://dx.doi.org/10.6084/m9.figshare.974481

42. Pichurin VV. Psychological and psycho-physical training as a factor of personal anxiety at students. Pedagogics, psychology, medical-biological problems of physical training and sports 2015;3:46-51. http://dx.doi.org/10.15561/18189172.2015.0307

43. Prosvirina LN, Kolokoltsev MM, Kolchanova MA, Cieslicka Miroslawa, Stankiewicz Blazej. The characteristic of the engine qualities of the students of technical institute of III functional health group (special medical group). Physical Education of Students 2015;1:43-49. http://dx.doi.org/10.15561/20755279.2015.0107

44. Siri A, Rui M. Distance Education for Health Professions' Students. Procedia - Social and Behavioral Sciences 2015;174(0):730-8.

45. Stanishevska TI, Gorna OI, Berezhniak AS, Horban DD. Daily dynamic of indicators of girl-students' blood microcirculation. Pedagogics, psychology, medical-biological problems of physical training and sport 2015;6:23-29. http://dx.doi.org/10.15561/18189172.2015.0604

46. Usher K, Woods C, Casella E, Glass N, Wilson R, Mayner L, et al. Australian health professions student use of social media. Collegian 2014;21(2):95-101. 
47. Yermakova TS. Individualization of forming health culture in schoolchildren of Polish schools. Pedagogics, psychology, medical-biological problems of physical training and sports 2015;1:29-33. http://dx.doi.org/10.15561/18189172.2015.0106

\section{Information about the authors:}

Martyniuk O.V.: http://orcid.org/0000-0002-2024-5326; nmusport@mail.ru; National Mining University; Karl Marx Av., 19, Dnipropetrovsk, 49600, Ukraine.

Vilyanskiy V.N.: http://orcid.org/0000-0002-2550-2643; nmusport@mail.ru; National Mining University; Karl Marx Av., 19, Dnipropetrovsk, 49600, Ukraine.

Cite this article as: Martyniuk O.V., Vilyanskiy V.N. Assessment of students' health condition by indicators of adaptation potential, biological age and bio-energetic reserves of organism. Physical education of students 2015;3:20-28. http://dx.doi.org/10.15561/20755279.2015.0303

The electronic version of this article is the complete one and can be found online at: http://www.sportpedu.org.ua/html/arhive-e.html

This is an Open Access article distributed under the terms of the Creative Commons Attribution License, which permits unrestricted use, distribution, and reproduction in any medium, provided the original work is properly cited (http://creativecommons.org/licenses/by/3.0/deed.en).

Received: 08.06.2015

Accepted: 29.06.2015; Published: 30.06.2015 